\title{
ZRÓŻNICOWANIE ZAAWANSOWANIA STAROŚCI DEMOGRAFICZNEJ NA OBSZARZE WOJEWÓDZTWA LÓDZKIEGO
}

\begin{abstract}
Streszczenie. Głównym celem artykułu jest analiza zmian w strukturze wieku populacji województwa łódzkiego, ze szczególnym uwzględnieniem procesu starzenia się ludności. Badanie to zostało przeprowadzone na poziomie powiatów i gmin, w oparciu o dane zaobserwowane na początku pierwszej i drugiej dekady XXI wieku a także na podstawie informacji pochodzących z prognoz ludnościowych GUS. Dodatkowo, dla wskazania szerszego kontekstu przemian w tym względzie, analizy na poziomie całego województwa zaprezentowane zostały dla lat 1995-2013. Tło dla tych rozważań stanowi przedstawienie obecnej sytuacji w zakresie struktury wieku populacji pozostałych województw Polski.
\end{abstract}

Słowa kluczowe: starzenie się populacji, zaawansowanie starości demograficznej, województwo łódzkie

\section{Wprowadzenie}

Rozkład wieku danej populacji determinowany jest przez wiele czynników, zarówno demograficznych (np. poziom dzietności, umieralność, migracje), jak i pozademograficznych (np. warunki życia, jakość opieki zdrowotnej, straty wojenne), w związku z tym ulega on zmianom w czasie. W Polsce przeobrażenia jakie zachodzą w strukturze wieku ludności od początku transformacji ustrojowej przejawiają się stopniowym wzrostem starszej subpopulacji przy zmniejszaniu się frakcji dzieci oraz ostatnio także i ludności w wieku produkcyjnym. Na obszarze całego kraju widoczny jest postęp procesu starzenia się populacji, choć stopień zaawansowania starości demograficznej jest wyraźnie zróżnicowany terytorialnie. Zróżnicowanie to jest także widoczne na obszarach poszczególnych województw.

Proces demograficznego starzenia się definiowany jest jako sukcesywny, systematycznie występujący wzrost udziałów osób starszych w populacji (Holzer 2003: 139; Okólski, Fihel 2012: 143), przy czym jako próg starości współcześnie najczęściej przyjmowany jest wiek 65 lat. Głównymi czynnikami determinującymi ten proces w krajach europejskich są spadek dzietności (znacznie poniżej poziomu gwarantującego prostą zastępowalność generacji, wynoszącego $2,1)$ oraz wydłużanie się przeciętnego dalszego trwania życia ludności. Istotne

\footnotetext{
* Dr, Zakład Demografii i Gerontologii Społecznej Uniwersytetu Łódzkiego.
} 
znaczenie w tym względzie mają również migracje. Następowanie po sobie kolejno niżów i wyżów demograficznych, czyli tzw. falowanie struktur, osłabia lub przyspieszają $\mathrm{w}$ danym okresie postęp zaawansowania starzenia się (Frątczak 2002: 22).

Głównym celem artykułu jest analiza zmian w strukturze wieku populacji województwa łódzkiego, ze szczególnym uwzględnieniem procesu starzenia się ludności. Badanie to zostało przeprowadzone na poziomie powiatów i gmin, w oparciu o dane zaobserwowane na początku pierwszej i drugiej dekady XXI wieku, a także na podstawie informacji pochodzących z prognoz ludnościowych. Dodatkowo, dla wskazania szerszego kontekstu przemian w tym względzie, analizy na poziomie województwa zaprezentowane zostały dla lat 1995-2013. Tło dla tych rozważań stanowi przedstawienie obecnej sytuacji w zakresie struktury wieku populacji pozostałych województw Polski.

W artykule zwrócono uwagę na województwo łódzkie z tego względu, że wyróżnia się ono pod względem demograficznym na tle pozostałych równorzędnych administracyjnie jednostek. Jest to najbardziej sfeminizowane ${ }^{1}$ oraz najstarsze demograficznie województwo w Polsce. Jednocześnie legitymuje się ono relatywnie niską wartością współczynnika dzietności ogólnej ${ }^{2}$, relatywnie niskimi wartościami przeciętnego dalszego trwania życia ${ }^{3}$ oraz ujemnym współczynnikiem salda migracji ${ }^{4}$. Ponadto w regionie tym (szczególnie na jego obrzeżach) obserwowana jest mało korzystna sytuacja na rynku pracy, $\mathrm{z}$ tego względu znaczna część jego mieszkańców (przy czym są to głównie osoby młode) decyduje się szukać zatrudnienia w innych regionach kraju (najczęściej jest to województwo mazowieckie).

Źródłem danych wykorzystanych w przeprowadzonych analizach były publikacje Głównego Urzędu Statystycznego dotyczące struktury wieku ludności w Polsce, województwach, a także w powiatach i gminach województwa łódzkiego. Uzyskane rezultaty zostały zaprezentowane graficznie $\mathrm{w}$ postaci tablic i wykresów.

${ }^{1} \mathrm{~W}$ woj. łódzkim w 2013 r. na 100 mężczyzn przypadało 110 kobiet (w miastach i na wsi odpowiednio 115 i 101). W województwie tym odnotowuje się także najwyższą wartość współczynnika feminizacji w grupie wieku 65+ lat - w 2013 r. na 100 mężczyzn tej grupy wieku przypadało 170 kobiet.

${ }^{2}$ W 2013 r. wartość ta w województwie łódzkim wynosiła 1,23 (w miastach i na wsi odpowiednio 1,15 i 1,37 ). Średnia dla Polski w tym roku wyniosła 1,26 (w miastach i na wsi odpowiednio 1,18 i 1,37$)$.

${ }^{3}$ Przeciętne dalsze trwanie życia noworodka urodzonego w 2013 r. w województwie łódzkim wynosiło dla mężczyzn i kobiet odpowiednio 70,7 oraz 80,1 lat (w miastach odpowiednio 70,8 i 80,0 lat, na wsi zaś odpowiednio 70,7 i 80,4 lat). Średnia dla Polski w tym względzie wynosiła dla mężczyzn i kobiet odpowiednio 73,1 i 81,1 (w miastach odpowiednio 73,5 i 81,1 lat), na wsi zaś odpowiednio 72,4 i 81,1 lat).

${ }^{4}$ W 2013 r. współczynnik salda migracji w województwie łódzkim wynosił $-1,1$ na 1000 ludności, przy czym w miastach jego wartość była ujemna $(-3,5)$, na wsi zaś dodatnia $(3,1$ na 1000 ludności). 


\section{Obraz struktury wieku populacji województwa lódzkiego na tle sytuacji w Polsce}

Obecnie, w Polsce frakcje najmłodsza i najstarsza są niemal równe liczebnie (zob. tabl. 1). W 2013 r. odsetek dzieci w wieku 0-14 lat wynosił 15\% i był wyższy na wsi niż w miastach (odpowiednio 16,7\% i 13,9\%), udział osób starszych zaś wynosił 14,7\%, przy czym był wyższy w miastach niż na wsi (odpowiednio $15,7 \%$ i $13,3 \%)$.

Tablica 1. Odsetki poszczególnych grup wieku (w \%) oraz mierniki relacyjne populacji Polski i województw w 2013 r. (stan na 31 XII), ogółem

\begin{tabular}{|c|c|c|c|c|c|c|c|}
\hline Województwo & $0-14$ & $15-64$ & $65+$ & $80+$ & $\begin{array}{l}\text { indeks } \\
\text { starości } \\
I S\end{array}$ & $\begin{array}{c}\text { Współczynnik } \\
\text { obciążenia } \\
W O\end{array}$ & $\begin{array}{l}\text { Współczynnik } \\
\text { sędziwej staro- } \\
\text { ści }^{5} \text { WSS }\end{array}$ \\
\hline Polska & 15,0 & 70,3 & 14,7 & 3,9 & 0,98 & 0,21 & 26,1 \\
\hline Dolnośląskie & 13,9 & 71,2 & 14,8 & 4,0 & 1,06 & 0,21 & 26,8 \\
\hline Kujawsko-pomorskie & 15,2 & 70,7 & 14,1 & 3,5 & 0,92 & 0,20 & 25,1 \\
\hline Lubelskie & 14,9 & 69,7 & 15,4 & 4,3 & 1,03 & 0,22 & 27,8 \\
\hline Lubuskie & 15,2 & 71,4 & 13,4 & 3,4 & 0,88 & 0,19 & 25,1 \\
\hline Łódzkie & 14,0 & 69,5 & 16,6 & 4,4 & 1,19 & 0,24 & 26,6 \\
\hline Małopolskie & 15,8 & 69,7 & 14,5 & 3,8 & 0,92 & 0,21 & 26,5 \\
\hline Mazowieckie & 15,5 & 69,1 & 15,4 & 4,4 & 0,99 & 0,22 & 28,3 \\
\hline Opolskie & 13,3 & 71,4 & 15,3 & 3,8 & 1,15 & 0,21 & 24,8 \\
\hline Podkarpackie & 15,5 & 70,4 & 14,0 & 3,8 & 0,90 & 0,20 & 26,9 \\
\hline Podlaskie & 14,5 & 70,1 & 15,3 & 4,6 & 1,06 & 0,22 & 29,8 \\
\hline Pomorskie & 16,3 & 70,2 & 13,5 & 3,4 & 0,83 & 0,19 & 24,9 \\
\hline Śląskie & 14,0 & 70,5 & 15,5 & 3,6 & 1,11 & 0,22 & 23,1 \\
\hline Świętokrzyskie & 14,0 & 69,9 & 16,1 & 4,5 & 1,15 & 0,23 & 27,8 \\
\hline Warmińsko- & 15,6 & 71,6 & 12,8 & 3,4 & 0,83 & 0,18 & 26,1 \\
\hline Wielkopolskie & 16,0 & 70,5 & 13,5 & 3,3 & 0,84 & 0,19 & 24,6 \\
\hline Zachodniopomorskie & 14,5 & 71,6 & 13,9 & 3,5 & 0,96 & 0,19 & 25,1 \\
\hline
\end{tabular}

Źródło: Opracowanie własne na podstawie GUS 2015.

Rozważając strukturę wieku populacji wszystkich województw można stwierdzić, że łódzkie legitymuje się jednym z najniższych odsetków dzieci w wieku 0-14 lat oraz osób w wieku 15-64 lata, przy najwyższym udziale subpopulacji w wieku 65+ lat (zob. tabl. 1). Tym samym, w woj. łódzkim odnotowuje się najwyższe wartości następujących mierników relacyjnych: indeksu starości $^{6}$ (gdzie, w 2013 r. na 100 dzieci w wieku 0-14 lat przypadało 119 osób

${ }^{5}$ Liczony jako iloraz liczby ludności w wieku $80+$ lat i frakcji w wieku $65+$ lat.

${ }^{6}$ Liczony jako iloraz liczby ludności w wieku 65+ lat do liczby dzieci w wieku 0-14 lat. Miernik ten może służyć ocenie stopnia zaawansowania starości demograficznej. Im jest 
w wieku 65+ lat) i współczynnika obciążenia osobami starszymi ${ }^{7}$ (gdzie, w $2013 \mathrm{r}$. na 100 osób w wieku 15-64 lata przypadały 24 osoby w wieku $65+$ lat). Relatywnie wysoki jest także odsetek osób w wieku $80+$ lat w populacji $(4,4 \%)$, a także indeks sędziwej starości (wskazujący, że w 2013 r. odsetek ludności w wieku $80+$ lat stanowił $27 \%$ subpopulacji osób w wieku $65+$ lat).

Spośród pozostałych województw wysokim stopniem zaawansowania starości demograficznej legitymują się świętokrzyskie, opolskie i śląskie, gdzie w 2013 r. odnotowano wysokie wartości indeksu starości $(1,1,-1,15)$, wynikające $\mathrm{z}$ relatywnie wysokiej frakcji osób $\mathrm{w}$ wieku $65+$ lat i względnie niskiego udziału dzieci w wieku 0-14 lat (zob. tabl. 1).

\section{Przemiany w strukturze wieku populacji województwa lódzkiego w latach 1995-2013}

Rozważając grupy wieku według kryterium biologicznego można zauważyć, że w województwie łódzkim w latach 1995-2013 odsetek dzieci w wieku 0-14 lat uległ wyraźnemu zmniejszeniu, wynosząc w końcu tego okresu 13,0\% i 15,6\% odpowiednio w miastach i na wsi (zob. rys. 1). Odsetek ludności w wieku 15-64 lata wykazywał tendencję rosnącą do 2009 r., która następnie uległa odwróceniu i w roku 2013 udział tej subpopulacji (zbliżony na wsi i w miastach) wyniósł $69,9 \%$ (zob. rys. 2). Natomiast udział ludności w grupie wieku 65+ lat znacząco wzrósł w tym okresie ${ }^{8}$ (zob. rys. 3), osiągając wartości wyższe w miastach (do 2010 r. odsetek ten był wyższy na wsi). W roku 2013 odsetek ludności starszej w województwie wynosił $16,6 \%$ (w miastach i na wsi odpowiednio $17,1 \%$ i $15,6 \%)$.

Należy podkreślić, że miasta i obszary wiejskie w województwie łódzkim legitymują się odmienną dynamiką zmian odsetka subpopulacji w wieku $65+$ lat - w pierwszym przypadku od połowy lat 90-tych obserwowana jest tendencja rosnąca, w drugim zaś malejąca (zob. rys. 4). Biorąc pod uwagę tylko lata 20022013 można stwierdzić, że w roku 2013 względem 2002 frakcja ta zwiększyła się o $23 \% \mathrm{w}$ miastach, na wsi zaś zmniejszyła o $3 \%$. Świadczy to o relatywnie wysokim postępie starości demograficznej w miastach. Na wsi zaś postęp ten jest nieco wolniejszy, aczkolwiek zauważalny.

\footnotetext{
on wyższy ponad wartość równą jeden (przyjmowanej jako próg starości (Kowaleski 2011: 24)), tym wyższe zaawansowanie tego stanu.

7 Liczony jako iloraz liczby ludności w wieku 65+ lat i liczby ludności w wieku 15-64 lata.

${ }^{8}$ Odsetek ludności w wieku $65+$ lat w roku 2010 był wyraźnie niższy niż dla pozostałych lat, co widoczne było w miastach jak i w Polsce ogółem (zob. rys. 3). Wynikało to z faktu relatywnie niższego stanu liczebnego grupy wieku 65-69 lat, tj. roczników urodzonych w czasie trwania drugiej wojny światowej.
} 

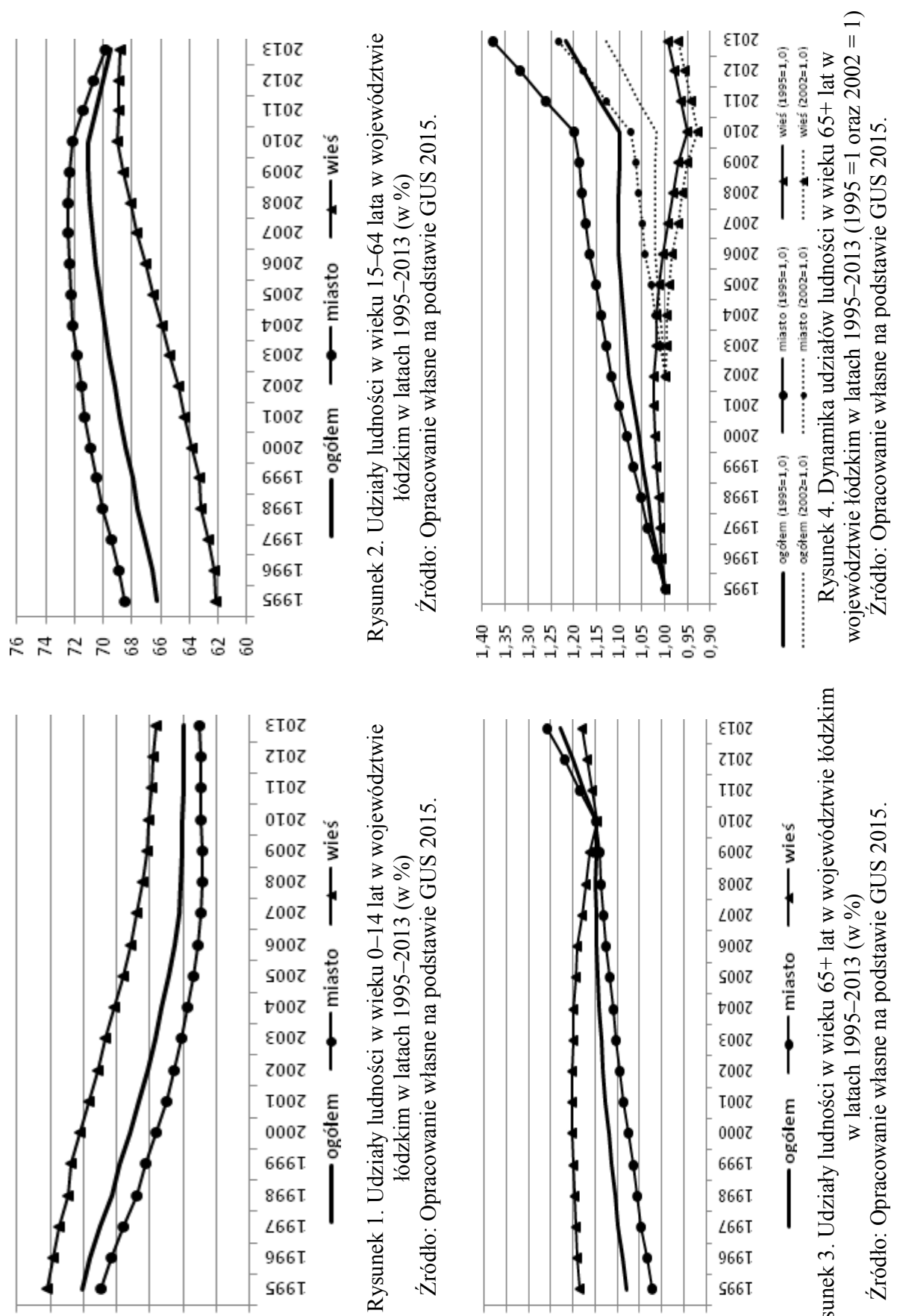

ㅊำ 워

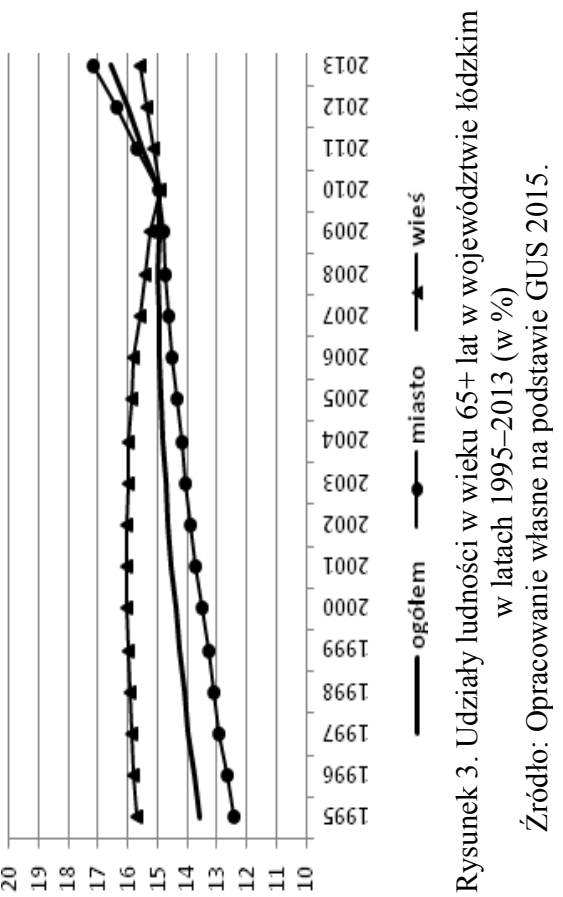


Odzwierciedleniem przeobrażeń w strukturze wieku populacji województwa łódzkiego w rozważanym okresie są wzrastające wartości indeksu starości (wyrażającego iloraz liczby ludności w wieku 65+ lat do liczby dzieci w wieku 0-14 lat), osiągające w latach 90-tych względnie niski poziom (zbliżony w miastach i na wsi), o ponad połowę niższy niż obecnie (zob. rys. 5). W roku 2013 na 100 dzieci w wieku 0-14 lat w miastach przypadało 130 osób w wieku $65+$ lat, na wsi zaś frakcje te były sobie równe. W latach 2002-2013 wartość omawianego miernika w miastach wzrosła o $38 \%$, na wsi zaś o $19 \%$, natomiast w okresie 1995-2013 indeks starości zwiększył się w miastach i na wsi odpowiednio o $100 \%$ i o $40 \%$ (zob. rys. 6 ).
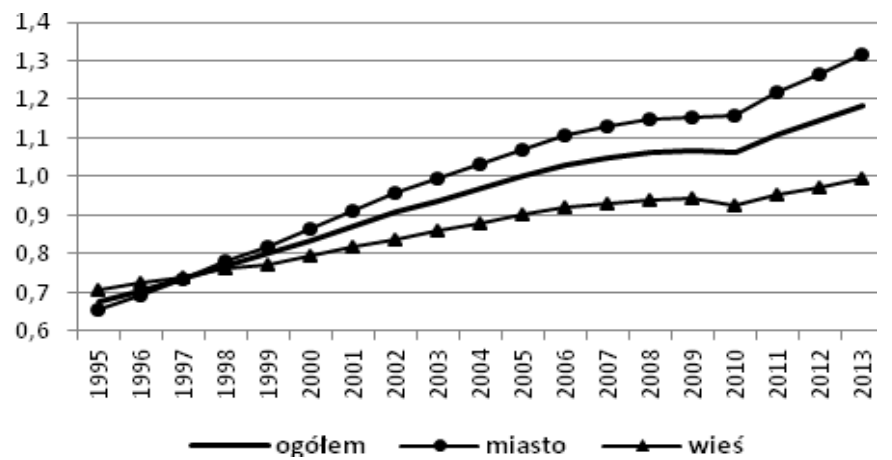

Rysunek 5. Wartości indeksu starości $\left(L_{65} / L_{0-14}\right)$ w województwie łódzkim w latach 1995-2013 Źródło: Opracowanie własne na podstawie GUS 2015

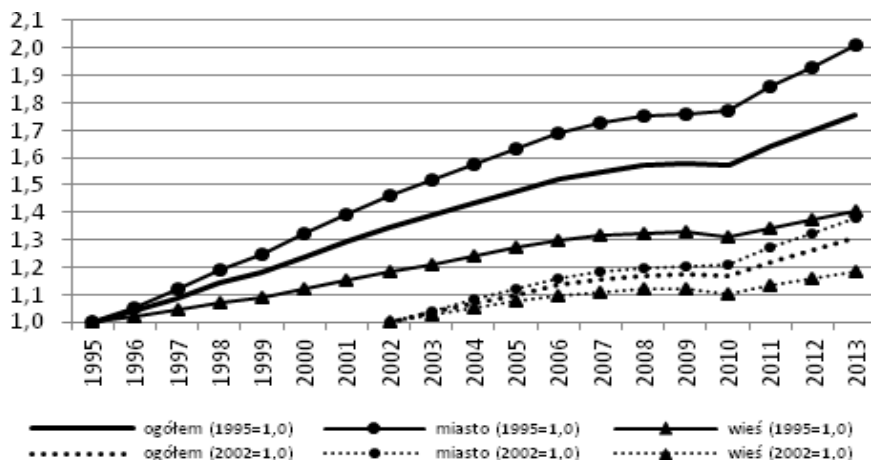

Rysunek 6. Dynamika indeksu starości $\left(L_{65} / L_{0-14}\right)$ w województwie łódzkim w latach 1995-2013 $(1995=1$ oraz $2002=1)$

Źródło: Opracowanie własne na podstawie GUS 2015. 
Przejawem przeobrażeń $\mathrm{w}$ strukturze wieku ludności są także zmiany w wartościach współczynnika obciążenia demograficznego osobami starszymi (zob. rys. 7). W miastach widoczna $\mathrm{w}$ tym względzie jest tendencja rosnąca w całym analizowanym okresie, na wsi zaś do roku 2010 tendencja ta miała charakter malejący, później wartości omawianego miernika zaczęły wzrastać. Obecnie, tj. według danych na koniec 2013 r., w Polsce na 100 osób w wieku 15-64 lata przypadają 24 osoby w wieku $65+$ lat (w miastach i na wsi odpowiednio 25 i 23 osoby). W latach 2002-2013 wartość tego miernika w miastach zwiększyła się o $26 \%$, na wsi zaś zmniejszyła o $9 \%$, natomiast biorąc pod uwagę okres 1995-2013 współczynnik ten wzrósł w miastach o 35\%, na wsi zaś jego wartość spadła o 10\% (zob. rys. 8).

Jak już zostało wspomniane, województwo łódzkie legitymuje się relatywnie wysokim udziałem ludności sędziwej, tj. w wieku 80+ lat (w 2013 r. wynoszącym 4,4\%), wykazującym od kilku lat wyraźny wzrost (zob. rys. 9). Tylko w latach $2005-2013^{9}$ frakcja ta zwiększyła się o $33 \%$ (w miastach i na wsi odpowiednio o $41 \%$ i $22 \%$ ). Należy podkreślić, że subpopulacja ta w województwie łódzkim w roku 2013 stanowiła 26,6\% ludności w wieku 65+ lat i była wyższa na wsi, o czym świadczą wartości współczynnika sędziwej starości (zob. rys. 10). W ostatnich kilku latach wartości tego miernika legitymowały się nieznacznym spadkiem, co wynikało przede wszystkim ze zwiększania się frakcji osób w wieku 65+ lat, stanowiącej mianownik tego współczynnika.

Na skutek obserwowanych w województwie łódzkim przeobrażeń w strukturze wieku populacji, tylko w latach 1995-2013 mediana wieku ludności wzrosła w miastach i na wsi odpowiednio o 5 i 3 lata (zob. tabl. 2). Zwiększeniu uległa także dysproporcja pomiędzy wartościami tego miernika w miastach i na wsi. W roku 2013 połowa mieszkańców województwa łódzkiego miała niespełna 41 lat lub mniej, połowa zaś niespełna 41 lat lub więcej (w miastach i na wsi wiek środkowy wynosił odpowiednio 41,9 oraz 38,2 lat) ${ }^{10}$.

Tablica 2. Mediana wieku populacji województwa łódzkiego w latach 1995-2013

\begin{tabular}{|l|c|c|c|c|c|c|c|c|c|}
\hline & 1995 & 2000 & 2002 & 2004 & 2006 & 2008 & 2010 & 2012 & 2013 \\
\hline Ogółem & 36,3 & 37,5 & 37,9 & 38,3 & 38,6 & 38,9 & 40,2 & 40,6 & 40,8 \\
\hline Miasto & 36,8 & 38,3 & 38,8 & 40,2 & 40,5 & 40,8 & 41,2 & 41,6 & 41,9 \\
\hline Wieś & 35,2 & 36,0 & 36,3 & 36,7 & 37,0 & 37,3 & 37,6 & 38,0 & 38,2 \\
\hline
\end{tabular}

Źródło: Opracowanie własne na podstawie GUS 2015.

${ }^{9} \mathrm{~W}$ publikacjach GUS nie są dostępne dane dotyczące tej frakcji dla lat wcześniejszych.

${ }^{10} \mathrm{~W}$ literaturze przedmiotu istnieje wiele mierników służących ocenie zaawansowania starości demograficznej. W niniejszej pracy zaprezentowane zostały miary najczęściej wykorzystywane. Więcej propozycji zostało opisanych m.in. w opracowaniu autorów J.T. Kowaleski i A. Majdzińska (2012). 


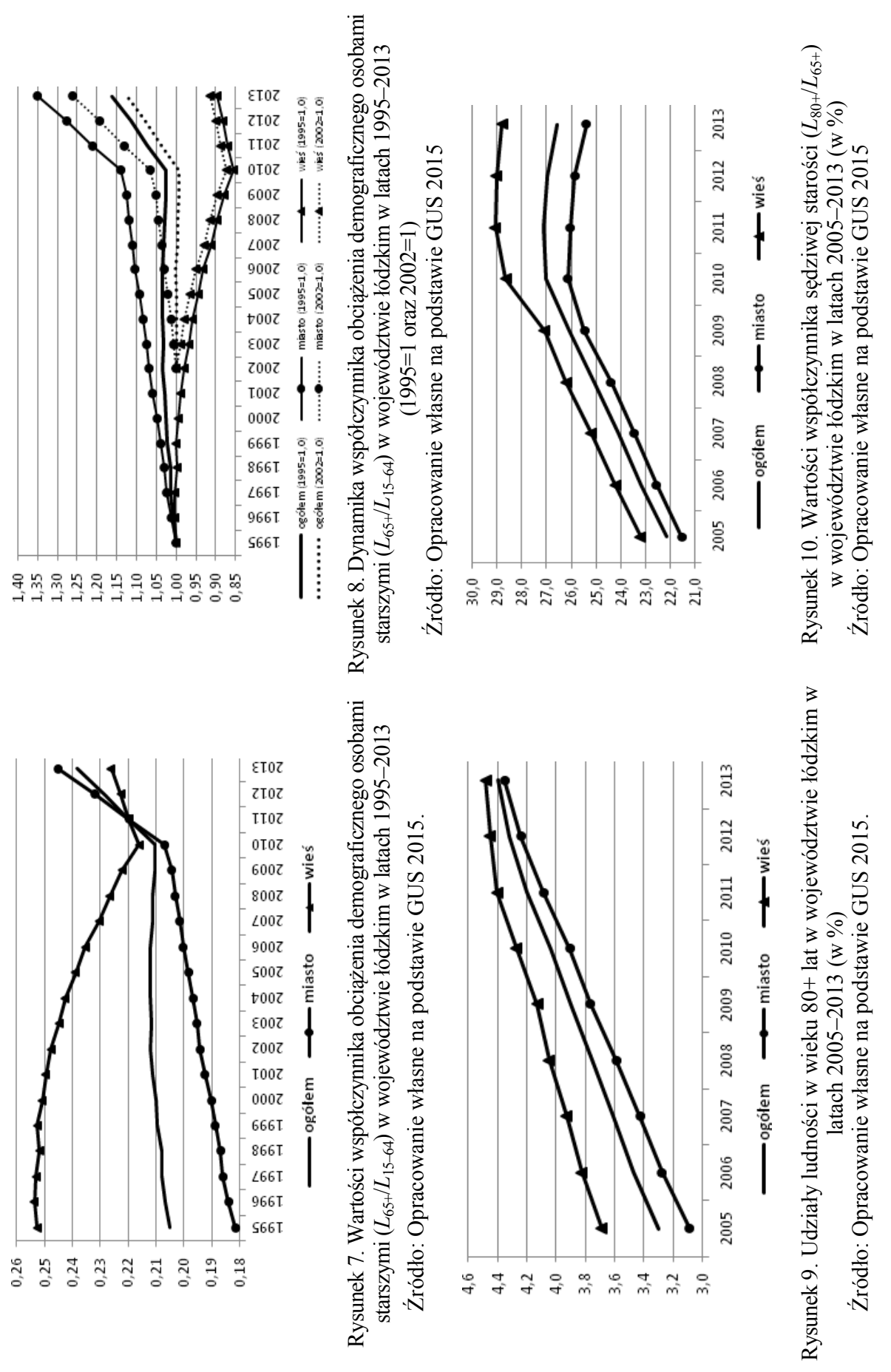




\section{Wewnątrzregionalne zróżnicowanie struktury wieku populacji województwa lódzkiego w latach 2002 i 2013}

Województwo łódzkie jest zróżnicowane wewnętrznie pod względem struktury wieku ludności, co widoczne jest zarówno na poziomie powiatów jak i gmin. W większości tych jednostek od kilku lub nawet kilkunastu lat obserwowany jest postęp procesu demograficznego starzenia się, objawiający się m.in. wzrostem udziału starszej części populacji, przy spadku frakcji najmłodszej.

Biorąc pod uwagę powiaty można stwierdzić, że w roku 2013 najniższym odsetkiem dzieci w wieku 0-14 lat legitymowała się Łódź (podobnie jak w roku 2002), a także powiaty kutnowski i pabianicki, najwyższym zaś piotrkowski, opoczyński, skierniewicki i wieruszowski (zob. tabl. 3 i rys. 11). W przypadku grupy środkowej (15-64 lata) w 2013 r. najniższym odsetkiem charakteryzował się powiat skierniewicki (podobnie jak w roku 2002), najwyższym zaś bełchatowski. Natomiast w 2013 r., tak jak w 2002 r., najmłodszą jednostką (biorąc pod uwagę odsetek osób w wieku 65+ lat) był powiat bełchatowski, najstarszą zaś miasto Łódź.

Rozważając dynamikę przemian w strukturach wieku populacji powiatów województwa łódzkiego zauważyć można, że w latach 2002-2013 we wszystkich tych jednostkach odnotowano spadek odsetka dzieci w wieku 0-14 lat (zob. tabl. 3) - najwyższy w powiatach sieradzkim i pajęczańskim (o ok. 23\%), najniższy zaś w Łodzi (o 3\%) i w Piotrkowie Trybunalskim (o 7,9\%). W przypadku grupy środkowej (15-64 lata) we wspomnianym okresie w większości powiatów nastąpił wzrost tej frakcji - najwyższy w powiecie skierniewickim (o 6,7\%), natomiast największy jej spadek zaobserwowany został w Łodzi i Piotrkowie Trybunalskim (o nieco ponad 3\%). Z kolei niemalże wszystkie powiaty w analizowanym okresie legitymowały się wzrostem subpopulacji w wieku $65+$ lat, najwyższym - Skierniewice (o 33,5\%) i Piotrków Trybunalski (o 28,9\%), najniższym zaś powiaty wieruszowski i opoczyński (o 4-5\%). Spadek tej frakcji odnotowany został $\mathrm{w}$ powiatach skierniewickim (o 7,1\%) oraz piotrkowskim (o $0,2 \%$ ). W Łodzi, czyli obecnie najstarszym demograficznie powiecie, subpopulacja ta zwiększyła się o $17 \%$.

W związku z przemianami w strukturze wieku, we wszystkich powiatach województwa łódzkiego w latach 2002-2013 zwiększeniu uległy wartości indeksu starości, co także świadczy o postępie demograficznego starzenia się tych jednostek (i całego województwa). Obecnie, podobnie jak na początku ubiegłej dekady, najwyższą jego wartością legitymuje się Łódź (gdzie w 2013 r. na 100 dzieci w wieku 0-14 lat przypadały 163 osoby w wieku 65+ lat, w roku 2002 zaś 135 osób), najniższą zaś powiat bełchatowski (gdzie w 2013 r. na 100 dzieci w wieku 0-14 lat przypadało 75 osób w wieku $65+$ lat, w roku 2002 zaś 52 osoby). Należy podkreślić, że w latach 2002-2013 wartości tego miernika wzrosły we wszystkich powiatach, przy czym wzrost ten był największy w powiecie kutnowskim, najmniejszy zaś w skierniewickim (zob. tabl. 3). 


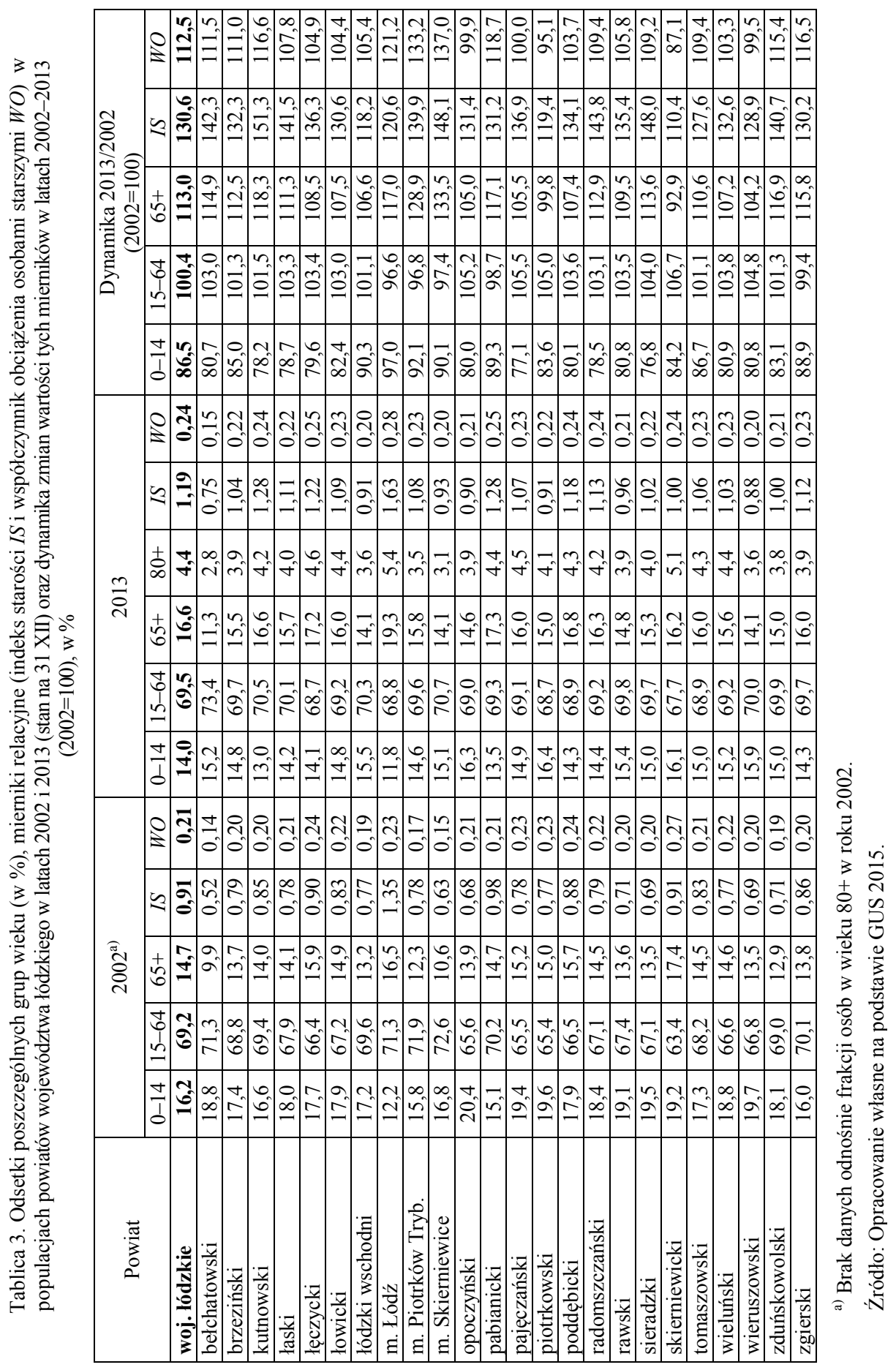


Biorąc pod uwagę współczynnik obciążenia osobami starszymi można stwierdzić, że w roku 2013 najwyższymi wartościami tego miernika charakteryzowała się Łódź, najniższymi zaś powiat bełchatowski (gdzie na 100 osób w wieku 15-64 lata przypadało odpowiednio 28 i 15 osób w wieku 65+ lat). $\mathrm{W}$ rozpatrywanym okresie $\mathrm{w}$ większości powiatów odnotowany został wzrost wartości tego współczynnika - najwyższy w Skierniewicach, spadek zaś miał miejsce w powiecie skierniewickim (zob. tabl. 3).

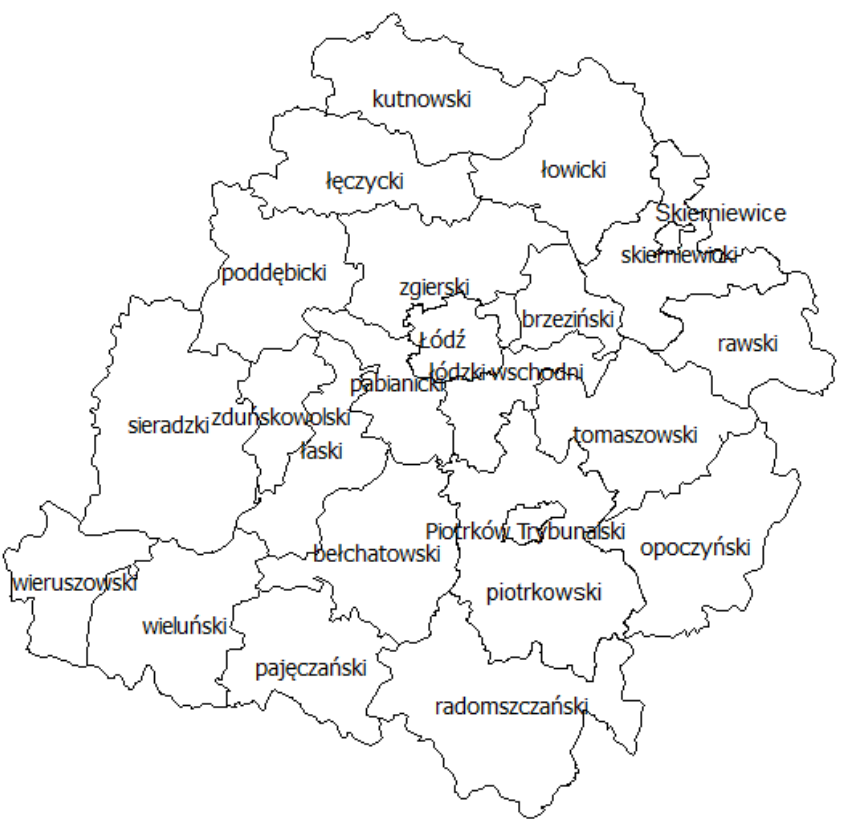

Rysunek 11. Powiaty w województwie łódzkim w 2013 r.

Źródło: Opracowanie własne w programie Quantum GIS.

Przechodząc na niższy poziom agregacji można stwierdzić, że spośród wszystkich gmin regionu łódzkiego (177) najwyższym zaawansowaniem procesu starzenia się ludności legitymują się jednostki wiejskie, w szczególności: Żytno, Zduny, Kiełczygłów, Bielawy, Poświętne, Widawa, Dąbrowice i Zadzim (w których w 2013 r. odsetek osób w wieku 65+ lat wynosił 19,0-19,6\%), najstarszą zaś gminą miejską jest miasto Łódź (19,3\%). Natomiast do jednostek najmłodszych demograficznie (tj. o najniższym udziale wspomnianej grupy wieku) zakwalifikować można miasto Bełchatów $(9,0 \%)$ oraz gminy wiejskie Kleszczów $(9,9 \%)$, Brójce $(11,2 \%)$, Nowosolną $(11,5 \%)$ oraz gminę wiejską Bełchatów (12,0\%). 
Łódź, jak wspomniano, spośród powiatów i gmin miejskich jest najstarszą demograficznie jednostką administracyjną $\mathrm{w}$ regionie, a jako miasto skupiające $28,3 \%$ populacji całego województwa ${ }^{11}$ silnie determinuje strukturę wieku całego tego regionu.

Do Łodzi w 2013 r. największe podobieństwo z punktu widzenia struktury wieku ludności wykazywały powiaty: pabianicki $(95,5 \%)$, Piotrków Trybunalski $(94,9 \%)$, a także kutnowski $(94,3 \%)$, najmniejsze zaś powiaty bełchatowski $(89,3 \%)$ i opoczyński $(89,7 \%)$. Wyższe zróżnicowanie w tym względzie obserwowane jest na poziomie gmin, spośród których w 2013 r. największe podobieństwo do Lodzi wykazywały: Pabianice (97,4\%), Kutno (96,5\%), Zgierz (95,9\%) oraz Konstantynów Łódzki (95,8\%) i Tomaszów Mazowiecki (95,7\%), najmniejsze zaś gmina wiejska Kleszczów $(82,7 \%)$, Brąszewice $(84,3 \%)$, Nowosolna $(85,9 \%)$, Dobryszyce $(86,6 \%)$, a także miasto Bełchatów $(86,6 \%)$.

Wspomniane podobieństwo pomiędzy Łodzią i pozostałymi powiatami oraz gminami zostało potwierdzone przy wykorzystaniu miar odległości ${ }^{12}$. Położenie w sensie metrycznym poszczególnych powiatów i gmin łódzkiego względem Łodzi z punktu widzenia odległości euklidesowych tych jednostek, uporządkowanych jednocześnie pod względem odsetka osób w wieku 65+ lat zostało zaprezentowane w postaci mapy dla obiektu ${ }^{13}$ (zob. na rys. 12 i 13).

Przedstawione mapy dla obiektu dwuaspektowo wskazują pozycje innych jednostek w stosunku do Łodzi z punktu widzenia struktury wieku oraz zaawansowania starości demograficznej. Jednostki najbardziej podobne do Łodzi pod względem całej struktury wieku zlokalizowane są na mniejszych półokręgach (w przypadku powiatów są to: powiat pabianicki, Piotrków Trybunalski oraz powiaty kutnowski i zgierski, w przypadku gmin zaś są to miasta: Pabianice, Kutno, Zgierz, Konstantynów Łódzki oraz Tomaszów Mazowiecki). Natomiast jednostki najmniej podobne do Łodzi zlokalizowane są na najdalszych półokręgach (w przypadku powiatów są to: powiat bełchatowski, opoczyński, skierniewicki, piotrkowski i wieruszowski, w przypadku gmin zaś: gminy wiejskie Bełchatów, Brąszewice, a także Dobryszyce, Nowosolna oraz miasto Bełchatów).

${ }^{11}$ Spośród pozostałych miast najwyższe udziały w zaludnieniu województwa w 2013 r. posiadały: Piotrków Trybunalski (3\%), Pabianice (2,7\%), Tomaszów Mazowiecki (2,6\%), Bełchatów $(2,4 \%)$, Zgierz (2,3\%), a także Skierniewice, Radomko i Kutno (1,8\%-1,9\%).

${ }_{12}$ Uporządkowanie jednostek względem Łodzi z punktu widzenia stopnia wzajemnego podobieństwa wykazanego przez wskaźnik podobieństwa struktur oraz odległości euklidesowe może być nieco inne, ze względu na różne sposoby obliczeń. Jednakże, różnice te nie są duże i zasadnicze wnioski w tym względzie są takie same.

${ }^{13}$ Mapa dla obiektu uwzględnia „odległości metryczne jednego wyróżnionego obiektu (czyli podobieństwo) względem wszystkich pozostałych obiektów oraz pozycje (wartości) wszystkich obiektów otrzymane w jakiejś procedurze rangowania" (Kolenda 2006: 157).

W prezentowanym badaniu mapa dla Łodzi została opracowana w oparciu o odległości euklidesowe wyznaczone na podstawie struktury wieku ludności gmin, natomiast porządkowanie jednostek zostało przeprowadzone w oparciu o odsetek ludności w wieku 65+ lat (oznaczony na promieniach półokręgu) pomiędzy Łodzią a pozostałymi gminami. 


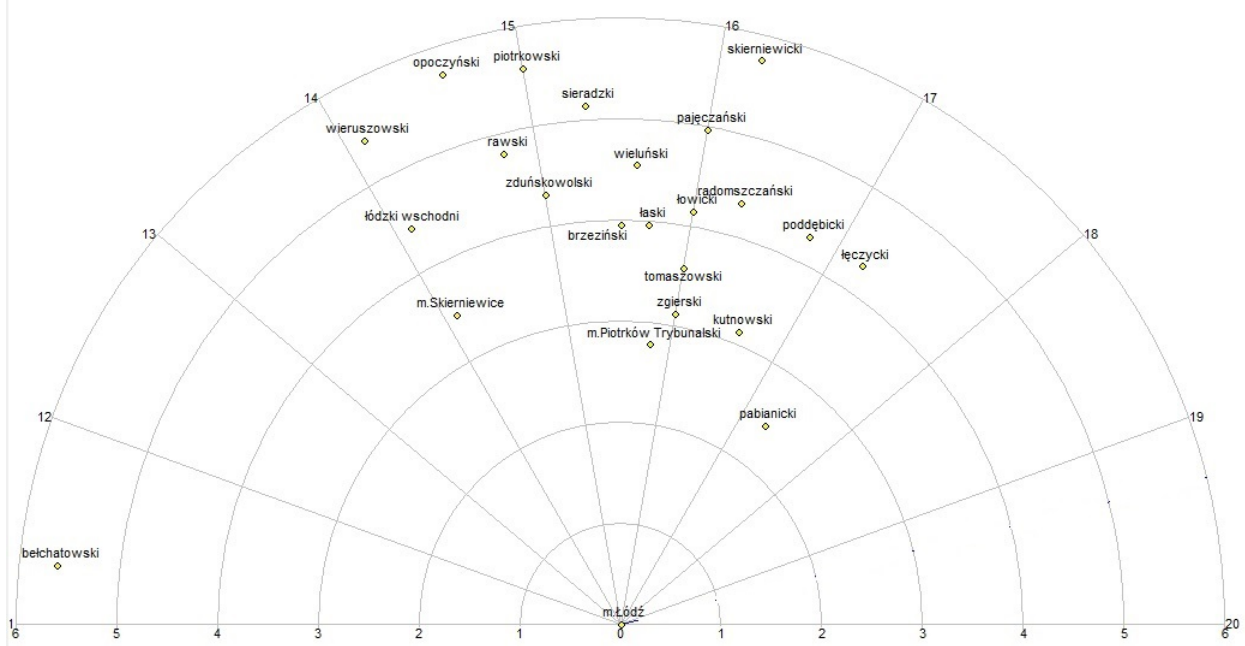

Rysunek 12. Odsetek ludności w wieku 65+ lat oraz odległości euklidesowe powiatów województwa łódzkiego względem miasta Łodzi z punktu widzenia struktury wieku ludności w 2013 r. (mapa dla obiektu)

Źródło: Opracowanie własne w programie Taksonomia numeryczna na podstawie GUS 2015

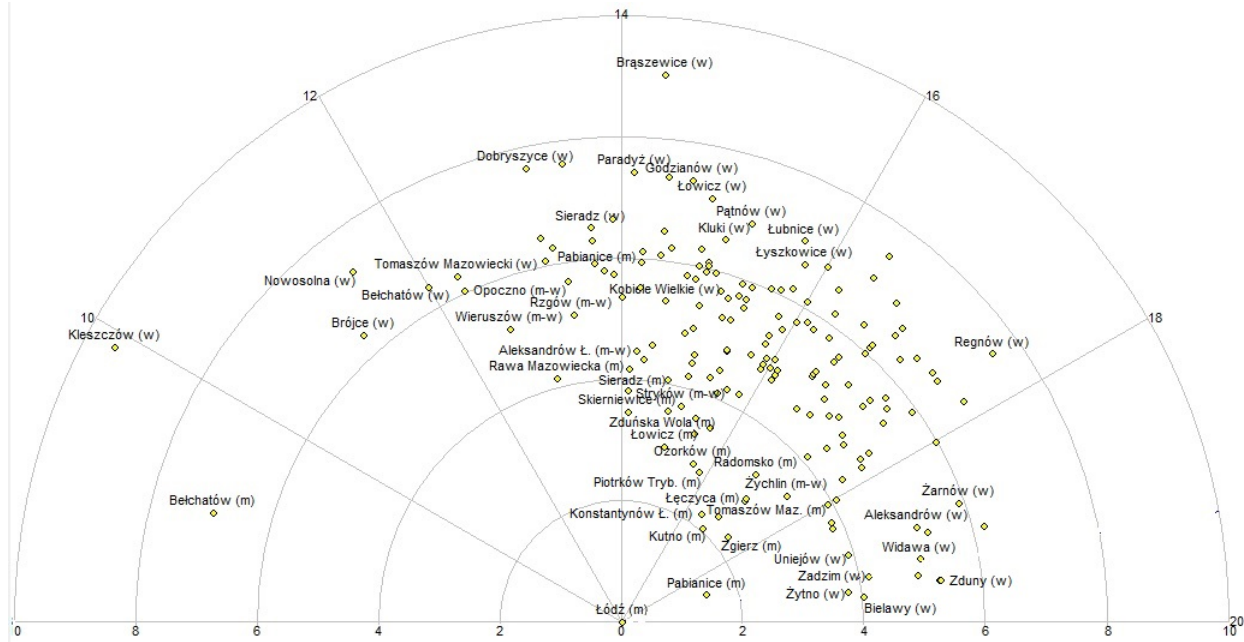

Rysunek 13. Odsetek ludności w wieku 65+ lat oraz odległości euklidesowe gmin województwa łódzkiego względem miasta Łodzi z punktu widzenia struktury wieku ludności w 2013 r. (mapa dla obiektu)

Źródło: Opracowanie własne w programie Taksonomia numeryczna na podstawie GUS 2015. 
$\mathrm{Z}$ kolei na promieniach uporządkowane są jednostki (odpowiednio powiaty i gminy) z punktu widzenia wartości odsetka osób w wieku 65+ lat - po lewej stronie wykresu jednostki relatywnie najmłodsze demograficznie, po prawej zaś najstarsze.

\section{Zaawansowanie starości demograficznej populacji województwa lódzkiego w świetle prognozy ludności}

W perspektywie najbliższych kilku- kilkunastu lat we wszystkich województwach Polski zaobserwowany zostanie postęp starzenia się ludności. Według wyników najnowszej prognozy ludności (opracowanej przez GUS w 2014 r.), w roku 2020 najwyższym odsetkiem ludności w wieku 65+ lat nadal legitymować się będzie województwo łódzkie (20,9\%), w 2030 zaś frakcja ta prawdopodobnie będzie najwyższa w świętokrzyskim i opolskim, a następnie w łódzkim (25-25,4\%). Obserwowany będzie także wzrost wartości indeksu starości w łódzkim w 2020 r. na 100 dzieci w wieku 0-14 lat przypadać będzie 150 osób w wieku 65+ lat, w roku 2030 zaś starsza $\mathrm{z}$ tych subpopulacji będzie dwukrotnie liczniejsza niż młodsza. W województwie tym prawdopodobnie odnotowana zostanie też jedna z najwyższych wartości współczynnika obciążenia demograficznego osobami starszymi (w latach 2020 i 2030 na 100 osób w wieku 15-64 lata przypadać będzie odpowiednio 32 i 40 osób w wieku 65+ lat).

W perspektywie najbliższych lat, we wszystkich powiatach województwa łódzkiego zaobserwowany zostanie wzrost zaawansowania starości demograficznej (zob. tabl. 5). Rozważając lata 2013-2020 w większości tych jednostek prawdopodobnie nastąpi spadek frakcji dzieci (największy w powiecie tomaszowskim, o 5,5\%), natomiast we wszystkich powiatach spadnie odsetek ludności w wieku 15-64 lata (najbardziej w Łodzi, o 8,3\%), wzrośnie zaś frakcja osób $\mathrm{w}$ wieku $65+$ lat (wzrost ten będzie najwyższy w powiecie bełchatowskim, o $44,4 \%)$.

W roku 2020 najwyższym odsetkiem ludności w wieku 65+ lat nadal legitymować się będzie Łódź $(24,8 \%)$ oraz powiat kutnowski i Piotrków Trybunalski (21,5\%), najniższym zaś powiat bełchatowski (16,4\%). W Łodzi odnotowane zostaną także najwyższe wartości indeksu starości (gdzie na 100 dzieci w wieku 0-14 lat przypadać będzie 205 osób w wieku 65+ lat) oraz współczynnika obciążenia osobami starszymi (gdzie na 100 osób w wieku 15-64 lata przypadać będzie 39 osób w wieku 65+ lat). Najniższe wartości tych mierników prawdopodobnie zostaną odnotowane w powiecie bełchatowskim (zob. tabl. 5). 


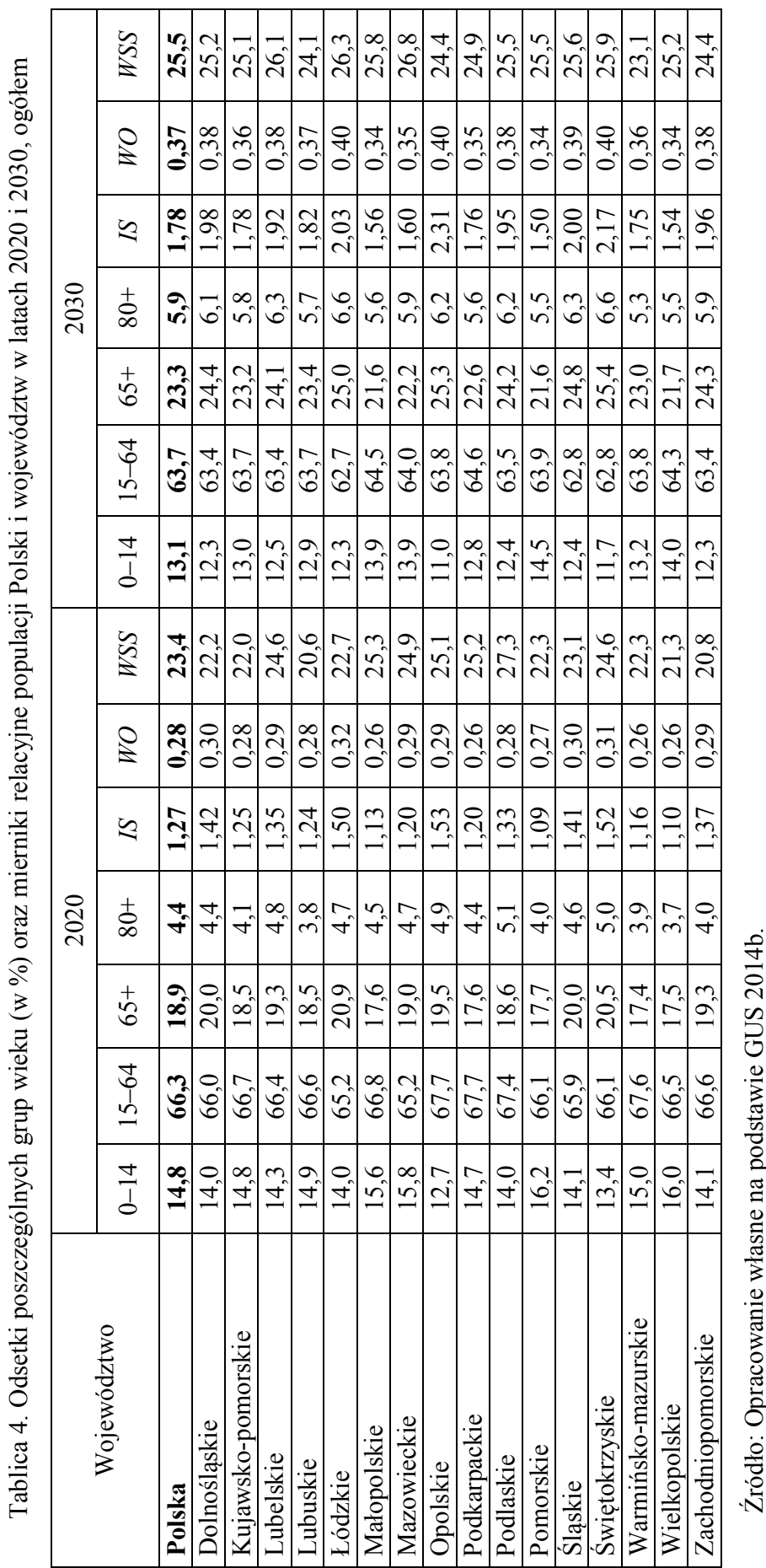


Tablica 5. Odsetki poszczególnych grup wieku (w \%), mierniki relacyjne (indeks starości IS i współczynnik obciążenia osobami starszymi $W O$ ) w populacjach powiatów województwa łódzkiego w 2020 r. oraz dynamika zmian wartości tych mierników w latach 2013-2020

$(2013=100), \mathrm{w} \%$

\begin{tabular}{|c|c|c|c|c|c|c|c|c|c|c|c|c|}
\hline \multirow{2}{*}{ Powiat } & \multicolumn{6}{|c|}{2020} & \multicolumn{6}{|c|}{$\begin{array}{c}\text { Dynamika 2020/2013 } \\
(2013=100 \%)\end{array}$} \\
\hline & $0-14$ & $15-64$ & $65+$ & $80+$ & $I S$ & $W O$ & $0-14$ & $15-64$ & $65+$ & $80+$ & $I S$ & $W O$ \\
\hline 1 & 2 & 3 & 4 & 5 & 6 & 7 & 8 & 9 & 10 & 11 & 12 & 13 \\
\hline woj. lódzkie & 14,0 & 65,2 & 20,9 & 4,7 & 1,5 & 0,32 & 99,7 & 93,8 & 125,8 & 107,7 & 125,7 & 133,5 \\
\hline bełchatowski & & & & & 1,0 & & 103,8 & 92,4 & 144,4 & 107,0 & 139,1 & 156,3 \\
\hline brzeziński & 4,4 & 65,9 & 19,7 & 4,3 & 1,3 & 0,30 & 97,2 & 94,5 & 127,4 & 111,2 & 131,1 & 134,7 \\
\hline kutnowski & 08 & 65,7 & 21,5 & 4,8 & 1,6 & 0,33 & 98,8 & 93,2 & 130,0 & 115,3 & 131,7 & 139,6 \\
\hline łaski & & & 19,3 & 4,3 & 1,3 & 29 & 98,2 & 95,2 & 123,1 & 106,5 & 125,3 & 129,3 \\
\hline łęczycki & & 4 & 20,4 & 5,2 & 1,4 & 0,31 & 100,7 & 95,2 & 118,4 & 113,4 & 117,5 & 124,3 \\
\hline łowicki & & 65,4 & 19,7 & 4,7 & 1,3 & 0,30 & 101,2 & 94,4 & 123,0 & 105,9 & 121,5 & 130,2 \\
\hline łódzl & & & & & 1,1 & & 100,0 & 94,7 & 126,5 & 98,2 & 126,6 & 133,6 \\
\hline m. $\mathrm{t}$ & & 3,1 & 24,8 & 5,7 & 2,0 & 0,39 & 102,2 & 91,7 & 128,1 & 104,6 & 125,3 & 139,7 \\
\hline m. Piotrków Tryb. & & & 21,5 & 4,4 & 1,5 & 0,33 & 97,1 & 92,5 & 135,7 & 125,4 & 139,8 & 146,8 \\
\hline m. Skie & & & & & 1,3 & & 100,3 & 91,8 & 140,7 & 126,8 & 140,3 & 153,2 \\
\hline opoczyński & & 66,3 & 17,9 & 4,4 & 1,1 & 0,27 & 96,5 & 96,0 & 122,6 & 113,0 & 127,1 & 127,6 \\
\hline pabianicki & & & 21,1 & 4,8 & 1,5 & 0,32 & 102,8 & 93,9 & 122,2 & 108,8 & 118,9 & 130,1 \\
\hline pajęczański & & & & & 1,3 & & & 96,4 & 118,8 & 105,7 & 123,2 & 123,2 \\
\hline piotrkowski & 150 & 66,4 & 17,7 & 4,3 & 1,1 & 0,27 & 97,1 & 96,8 & 118,0 & 105,8 & 121,6 & 121,9 \\
\hline poddębicki & & & 20,1 & 4,8 & 1,3 & 0,31 & 101,6 & 95,0 & 119,3 & 111,9 & 117,5 & 125,6 \\
\hline radomsz & & & & & 1,4 & & & 95,5 & 124,0 & 114,8 & 131,0 & 129,9 \\
\hline rawski & 15,8 & 65,6 & 18,6 & 4,3 & 1,1 & 0,28 & 102,7 & 94,1 & 125,1 & 109,7 & 121,9 & 133,0 \\
\hline sieradzki & & 66,5 & 18,8 & 4,3 & 1,2 & 0,28 & 98,2 & 95,3 & 123,2 & 108,8 & 125,4 & 129,2 \\
\hline skierniewicki & & & 18,0 & 4,9 & 1,0 & 0,28 & 103,1 & 96,6 & 111,3 & 94,5 & 108,0 & 115,3 \\
\hline tomaszowski & 14,2 & 65,3 & 20,5 & 4,8 & 1,4 & 0,31 & 94,5 & 94,7 & 128,0 & 111,0 & 135,5 & 135,2 \\
\hline wieluński & 14,9 & 66,0 & 19,1 & 4,5 & 1,2 & 0,29 & 98,2 & 95,4 & 122,2 & 103,2 & 124,4 & 128,0 \\
\hline wieruszowski & & 67,2 & 17,6 & 3,8 & 1,1 & 0,26 & 95,6 & 96,0 & 125,1 & 107,5 & 130,9 & 130,4 \\
\hline zduńskowolski & 15,0 & 66,1 & 18,9 & 4,1 & 1,2 & 0,29 & 99,8 & 94,6 & 125,5 & 110,5 & 125,6 & 132,7 \\
\hline zgierski & 14,1 & 65,7 & 20,2 & 4,3 & 1,4 & 0,31 & 99,1 & 94,1 & 126,3 & 110,6 & 127,4 & 134,2 \\
\hline
\end{tabular}

Źródło: Opracowanie własne na podstawie GUS 2014c.

\section{Podsumowanie}

Województwo łódzkie legitymuje się względnie wysokim stopniem zaawansowania starości demograficznej, przy znacznym zróżnicowaniu wewnątrzregionalnym w tym względzie. Świadczy o tym relatywnie wysoki odsetek osób w wieku 65+ lat, wyższy niż frakcja dzieci w wieku 0-14 lat (odsetek tej subpopulacji oraz wartości indeksu starości obecnie są najwyższe spośród pozostałych województw). Stolica tego regionu, czyli Łódź, jest najstarszym demograficznie powiatem, a także najstarszą gminą miejską w tym województwie. Wysoki sto- 
pień zaawansowania starości demograficznej tego miasta wynika przede wszystkim z niskiej wartości współczynnika dzietności, a także ujemnego salda migracji.

W perspektywie kolejnych kilku i kilkunastu lat zaawansowanie starości demograficznej na obszarze łódzkiego będzie wzrastać, podobnie jak w pozostałych regionach kraju. Województwo to, obok świętokrzyskiego i opolskiego, nadal legitymować się będzie relatywnie wysokim odsetkiem subpopulacji osób starszych. W jednostkach tych pogłębiać się będzie liczebna różnica pomiędzy frakcjami najmłodszą i najstarszą.

Jak już wspominano, zmiany w strukturze wieku objawiające się postępem zawansowania starości demograficznej, obserwowane nie tylko na obszarze województwa łódzkiego, niosą za sobą wiele konsekwencji, w tym negatywnych. Do najpoważniejszych z nich należą następstwa ekonomiczne (m.in. spadek wielkości potencjalnych zasobów pracy, spadek wydolności finansowej systemu emerytalnego), a także społecznych (m.in. wzrost zapotrzebowania na pomoc instytucjonalną wśród osób sędziwych) ${ }^{14}$. Następstwa te należy postrzegać perspektywicznie, a odpowiednie działania, mające na celu m.in. ich łagodzenie, podejmować już teraz.

\section{Bibliografia}

GUS (2014a), Rocznik Demograficzny 2014, Warszawa

GUS (2014b), Prognoza ludności na lata 2014-2050, Warszawa

GUS (2014c), Prognoza dla powiatów i miast na prawie powiatu oraz podregionów na lata 20142050 (opracowana w 2014 r.), http://stat.gov.pl/obszary-tematyczne/ludnosc/prognozaludnosci/prognoza-dla-powiatow-i-miast-na-prawie-powiatu-oraz-podregionow-na-lata-

2014-2050-opracowana-w-2014-r-,5,5.html (dostęp w dn. 14.01.2015 r.)

GUS (2015), Bank Danych Lokalnych, http://stat.gov.pl/ (dostęp w dn. 11.01.2015 r.)

Frątczak E., 2002, Proces starzenia się ludności Polski [w:] „Studia Demograficzne”, nr 2(142), PAN, Warszawa

Holzer J.Z. (2003), Demografia, PWE, Warszawa

Kolenda M. (2006), Taksonomia numeryczna. Klasyfikacja, porządkowanie i analiza obiektów wielocechowych, Wydawnictwo Akademii Ekonomicznej we Wrocławiu, Wrocław

Kowaleski J.T. (2011), Struktura demograficzna starszego odłamu ludności w województwach (stan aktualny i prognozy do roku 2030) [w:] Kowaleski J.T. (red.), Przestrzenne zróżnicowanie starzenia się ludności Polski. Przyczyny, etapy, następstwa, Wydawnictwo Uniwersytetu Łódzkiego, Łódź

Kowaleski J.T., Majdzińska A. (2012), Miary i skale zaawansowania starości demograficznej [w]: Rossa A. (red.), Wprowadzenie do gerontometrii, Wydawnictwo Uniwersytetu Łódzkiego, Łódź

Kurkiewicz J. (red.) (2012), Demograficzne uwarunkowania $i$ wybrane spoleczno-ekonomiczne konsekwencje starzenia się ludności w krajach europejskich, Wydawnictwo Uniwersytetu Ekonomicznego w Krakowie, Kraków

Okólski M., Fihel A. (2012), Demografia. Wspótczesne zjawiska i teorie, Wydawnictwo Naukowe Scholar, Warszawa

${ }^{14}$ Szerzej o konsekwencjach starzenia się populacji europejskich, zarówno ekonomicznych jak i społecznych, traktuje publikacja pod red. J. Kurkiewicz (2012). 


\title{
SPATIAL DIFFERENTIATION OF THE POPULATION AGEING PROCESS IN LODZKIE VOIVODESHIP
}

\begin{abstract}
The main aim of this paper is the analysis of the changes in lodzkie voivodeship population structure with the focus on the population ageing process. The research was conducted at the beginning of the first and second decade of the 21 st century and in the near future for poviats and gminas. In addition, to indicate the broader context of the developments in this regard, the analyses for this voivodeship were carried out for the years 1995-2003. The current situation was presented against the population age structure of other Polish regions.
\end{abstract}

Keywords: population ageing process, lodzkie voivodeship. 